\title{
The Chaebol's contribution on South Korea nation branding through Korean wave
}

\author{
Sarah Amirah Dannitaa,1, Shannaz Mutiara Deniarb,2,* \\ ab Universitas Muhammadiyah Malang, Jalan Raya Tlogomas No. 246 Malang, 65144, Indonesia \\ ${ }^{1}$ sarahadannita@gmail.com; 2shannaz.deniar@gmail.com
}

* Corresponding Author

\begin{tabular}{|c|c|}
\hline INFO ARTIKEL & ABSTRAK \\
\hline $\begin{array}{l}\text { Sejarah Artikel: } \\
\text { Diterima: } 31 \text { Juli } 2021 \\
\text { Direvisi: } 2 \text { September } 2021 \\
\text { Disetujui: 22 September } 2021 \\
\text { Tersedia Daring: } 31 \text { Oktober } \\
\text { 2021 } \\
\text { Kata Kunci: } \\
\text { Chaebol } \\
\text { CJ Group } \\
\text { Lotte Group } \\
\text { Nation Branding } \\
\text { Gelombang Korea }\end{array}$ & \multirow[t]{2}{*}{$\begin{array}{l}\text { Korean Wave atau yang dikenal dengan Hallyu Wave menjadi salah satu } \\
\text { ciri nation branding dari Korea Selatan. Sebagai sebuah kebutuhan dari } \\
\text { negara untuk memperkuat eksistensinya, kajian mengenai nation } \\
\text { branding menjadi menarik untuk melihat bagaimana strategi yang } \\
\text { dipilih dari aktor negara serta bagaimana bentuk kolaborasi yang } \\
\text { mereka lakukan. Penelitian ini menelaah kontribusi Chaebol dalam } \\
\text { penguatan nation branding melalui Korean Wave. Dengan } \\
\text { menggunakan Nation Branding Index oleh Simon Anholt, penelitian ini } \\
\text { melihat bagaimana bentuk kontribusi dan kolaborasi antar aktor dalam } \\
\text { enam index, yakni national governance, export promotion, tourism, } \\
\text { investment and immigration, cultural/heritage relations, dan public/ } \\
\text { people. Hasil penelitian ini memperlihatkan usaha Chaebol melalui } \\
\text { kerjasama, joint venture, produksi, distribusi, serta promosi konten- } \\
\text { konten dalam hallyu terlihat berdampak signifikan baik dalam citra } \\
\text { promosi maupun pemasaran produk kepada masyarakat internasional. } \\
\text { ABSTRACT }\end{array}$} \\
\hline & \\
\hline $\begin{array}{l}\text { Keywords: } \\
\text { Chaebol } \\
\text { CJ Group } \\
\text { Lotte Group } \\
\text { Nation Branding } \\
\text { Hallyu Wave }\end{array}$ & $\begin{array}{l}\text { The Korean Wave, also known as the Hallyu, is one of the nation branding's } \\
\text { characteristics of South Korea. As a need from the state to strengthen its } \\
\text { existence, the study of nation branding is interesting to see how the } \\
\text { strategies chosen by state actors are and what forms of collaboration they } \\
\text { take. This study will examine the contribution of Chaebol in strengthening } \\
\text { nation branding through the Korean Wave. By using the Nation Branding } \\
\text { Index by Simon Anholt, this study looks at the forms of contribution and } \\
\text { collaboration between actors in six nation branding indexes, namely } \\
\text { national governance, export promotion, tourism, investment and } \\
\text { immigration, cultural/heritage relations, and public/people. The results of } \\
\text { this study show that Chaebol's strategies through cooperation, joint } \\
\text { ventures, production, distribution, and promotion of hallyu content has a } \\
\text { significant impact both in image promotion and product marketing to the } \\
\text { international community towards South Korea. }\end{array}$ \\
\hline
\end{tabular}

(c) 2021, Dannita \& Deniar

This is an open access article under CC-BY-SA license branding through Korean wave. Satwika : Kajian Ilmu Budaya dan Perubahan Sosial, 5(2), 317-336, https://doi.org/10.22219/satwika.v5i2.17609

\section{Introduction}

When it comes to South Korean culture, people will generally refer to Korean Pop or K-Pop which has been popular in the East
Asian market since the 1990s. Korean Wave or known as Hallyu Wave is the global phenomenon of the South Korean entertainment industry, including music, 
film and television series (Kim, 2015). Although Hallyu initially appeared due to the popularity of Korean drama (K-Drama) and followed by K-Pop, but it expand to diverse content classified it in 11 sections related to the culture and lifestyle of South Korean society including broadcasting programs (drama, variety and reality shows), movies, music (K-Pop), art performances, video games, manhwa (comics), publications (books, novels), fashion, cosmetics, food \& beverages, and also tourism (Lee, 2020).

As a commodity, Hallyu content not only benefits in terms of the economy, but aims to improve its positive image and narrow the gap between the world community's perception of the country's culture. Hallyu it is now part of South Korean nation branding which attract the international community from its cultural industry content. The Hallyu distribution is not only carried out by the South Korean government itself, but there are contributions from other parties with their respective roles. The government as the main actor who creates and regulates the course of policy, then the private party dominated by business sector as the creator of the products, distributors, and the investors of Hallyu products. This large business group lead by majors company known as chaebol, a groups of conglomerate network in South Korea controlled by a centralized family system. They have a very big role for the development of South Korea since decades ago, so there is no denying they do have such close relations with the government, given its great role for the country. It consists of many subsidiaries companies under a very wide chaebol network system and has a clear structure and arrangement of companies included in it. Culturally, chaebol is more than just a dynasty. Chaebol acts not only as an object of national economic policy, but also a major subject besides the government in managing businesses that make the national interest the highest priority (Jung, 2004).
The legacy of Confucianism in South Korea shows that in everyday life including in business, they uphold communal success, in stark contrast to western cultures that in driving corporate success tend to focus on individual contributions. This is implemented in chaebol work systems that show that they carry a network system or family group in which there is no separation between ownership and control. This is what distinguishes chaebol from conglomerate business groups in other countries. The first generation of Chaebol companies generally established in 1930 to the mid-1950s, because chaebol has a short history or has not reached a decade so many founders of the company still occupy a leading position in the management of the company, which subsequently the transfer of ownership or authority to manage the company will be handed down to the family of the founder's blood (Campbell \& Keys, 2002).

Due to chaebol, South Korea has a proven export achievement by ranking 5th among other world exporter countries as well as ranked 11th for GDP if sorted according to official data from the IMF (Dilinger, 2018). Recorded in 2019, 64 chaebol companies accounted for $84.3 \%$ of South Korea's total GDP or 1,617 trillion won (Song, 2020). With the top 5 GDP contributor companies in the same year among them are Samsung, Hyundai Motor, SK, LG, and Lotte (Kim, 2020).

KFTC (Korean Fair Trade Commission) stated that the total value of assets currently used as indicators in measuring the chaebol category to a minimum of 5 trillion won, while announcing a list of companies belonging to the chaebol group in South Korea, CJ Group and Lotte Group Company were on the list which CJ Group has total assets of 31.1 trillion won with 75 affiliated companies and lotte group's asset value of 115.3 trillion won along with 95 affiliated companies below (Chae, 2019). This indicates that CJ and Lotte Group have criteria set by KFTC in proving that they are part of a chaebol business group. Among other chaebol companies the two companies 
are the closest to Hallyu because of the superior products they create and distribute related to the culture and lifestyle of South Korean people. It was stated by CJ Group on the company's official website that it has a target value and purpose to promote South Korean culture through its products with global business expansion. Similarly Lotte claims that their company has been promoting and marketing Hallyu products since 2004, and significantly assisting the development of South Korean tourism. And they implement this in their business system that adheres to the foundation of culture and collaborates with technology, it is proven to be realized in every product they assisted to promote Brand Korea as country, society, tourist destination, and an origin of manufacture product produced by chaebol (Walsh, 2014). The products in question are not only physical goods such as traditional food exported to be known by the global community, but also a variety of broadcast content, concert performances, conventions, with cooperation that is often done with the government that will be discussed more deeply in the discussion section.

In this research, we used Nation Branding Index which initiated by Simon Anholt, a British branding consultant. Nation branding is an activity through strategies that aim to measure, build, and manage the reputation of the country (closely related to placing brands), such as increasing the symbolic value of products that can also have an impact on improving the characteristics of a country, because it is very important with what they actually produce and sell to the world (Anholt, 2013).

Basically, the background of nation branding is innovation. It can also indicate differentiation from one country to another. When the innovation has been proven from a country, then be prepared to get international recognition, not only effectively improve the situation but also become an investment in the economic aspect of the country. A brand should be treated as a component of the country's national policies, which are inseparable from planning, governance, and economic development (Anholt, 2013). Therefore, in shaping the image / brand of the country, the target branding is not only intended for a name, symbol, and figure which is a combination of the identity of a country. However, it is recommended that a country can focus and prioritize the development and marketing of products internationally (Rahayu \& Arianti, 2014). Nation branding also proved as the marketing strategies of hallyu product in other region like ASEAN (Kim \& Park, 2020) or country like Vietnam (Nguyen \& Özçaglar, 2021).

The thing that distinguishes with the theory or concept of similar from other figures is Simon Anholt created the gauge nation branding itself with 6 elements called Nation Branding Index namely National Governance, Export Promotion, Tourism, Investment and Immigration, Cultural/ heritage relations, and public/ people. National Governance describe as a measure of public opinion on the level of competence and fairness of national government leadership, and describes the trust of both individuals and the public at large with the government in each of these countries, as well as the commitment made to global issues. Export Promotion is the perceptions of the products and services of each country, or the public's view of the contribution to innovation in science and technology. Meanwhile Investment \& Immigration is how the public judges a country from the economic and social aspects. The country is seen as the right place to live, work, invest, and study. On the other hand, tourism index is a measure of the level of interest in visiting a country and all its natural attractions, historical buildings, and city entertainment. Related to that, cultural/heritage relations explains the global perception of a country's culture and heritage, appreciating contemporary culture, be it music, film, as well as in the field of sports. Of course we shouldn't omit the society itself, on how he public's view of a country's reputation for the potential, feasibility, and openness of its people, both as a whole and personally. 
The concept of branding itself coming from business and marketing sectors but in term of nation branding, the collaboration between public and private sector become crucial. The government as the main actor who creates and regulates the course of policy, then the private party dominated by business sector as the creator of the products, distributors, and the investors of Hallyu products (Choi \& Kim, 2014). Through this concept, researchers will discuss the Public Private Partnership (PPP) between the South Korean government and the chaebol especially CJ and Lotte Group. PPP is a relationship between the government and various public parties, both private companies, communities, and NGOs that have their respective roles in efforts to build the country in all aspects including the economic sector through investment and a series of cooperation (Aziz, 2016). This is based on the close relationship between the South Korean government and chaebol since the implementation of the export orientation policy in the 1960s (Yoo, 2008). This research will explain the contribution of chaebols and its collaboration with government in maintaining and promoting the nation branding.

However, not all of the elements mentioned above have the same proportion to be able to explain the contribution that chaebol has as a non-state actor in encouraging the addition of state brand value. Because, the methodology function of this concept is the state actor, then the element is more precise and can be used to explain and measure how much collaborations and what contributions the conglomerate company has made in the hallyu and the impact on the development of the nation branding of the South Korean state refers to elements of government, export, tourism, and investment \& immigration.

Meanwhile, the other two which are culture and heritage and public/people tends to be the result of collaboration efforts chaebol and government in four previous elements. Because culture is basically as an object of their branding and is a thing that has become the identity of a country so that even without the participation of chaebol then this element can still run independently. Then in the public element, from various branding activities carried out by the government and chaebol there are also other parties such as entertainment industry agencies, including idols, actors, and artists, as well as local South Korean communities, especially K-fans hallyu and fansite, who have their respective contributions and roles in encouraging the development of hallyu globally.

\section{Method}

This study discusses the points of the extent of the role of chaebol specifically CJ and Lotte Group companies with their collaboration with the South Korean government in contributing to the branding of the South Korean state through the phenomenon of hallyu wave, the author uses descriptive research methods in order to describe this phenomenon in detail, convey factual and actual data, and then elaborate it with relevant concepts to the results processed data that researchers analyzed (Levy, 2009).

Data collection techniques that the author uses are library research, namely by collecting theoretical data, exploring data, studying a number of literature processed from various sources and related agencies related to the problems studied either in the form of books, journals, documents, thesis, papers, reports, articles, and information from print media and other electronic media relevant to the observed problems mainly about the Chaebol's conglomerate like CJ and Lotte Group in promoting hallyu content trough their business expansion and marketing strategies. The author also looked up on government strategies on its nation branding strategies especially toward Hallyu. The theoretical data will be analyzed and processed to answer problems in the research. Analysis of this research is conducted by deduction technique, the data related to the problem will be examined in 
detail and then will be tested with the concept of nation branding in the form of hexagonal has 6 elements as the basis of analysis in this research that affects the process of forming the main argument.

\section{Result and Discussion}

\subsection{South Korean's Nation Branding}

As explained in the previous chapter that the South Korean government used culture as a tool to rebuild the country after the financial crisis in the late 1990s, so the government is very concerned about policy movements and organizes it organized under the auspices of MCST (Ministry of Culture, Sports, and Tourism). However, in 2008 Simon Anholt and another nation branding observer Keith Dinnie considered that the value of the South Korean brand was still low. The government finally realized the importance of strengthening the brand for the progress of the country in all aspects, in the same year president Lee Myung Bak formed the PCNB (Presidential Council on Nation Branding) which focuses on controlling all agendas of South Korea's nation branding with initial financing prepared for 100 billion Won for a smooth branding strategy. Although PCNB do not continue in the next government, hallyu branding and promotion activities continue to be carried out by MCST and the institutions under it.

As for South Korea's soft power according to The Place Brand Observer, a research center by experts in the field of branding studies, strong enough to occupy the position of 14 , the most prominent of these brands is the source of their soft power that is content that is part of hallyu such as K-pop, K-drama, K-food, K-beauty, and other content that has grown and gained attention as well as popularity on the international stage. For the business sector, the global outlook on South Korea is the ease and effectiveness of doing business in the country is good enough to occupy position 5 even above that of the United States. The quality of South Korea's business rate is ranked quite highly with an assessment of the highest supporting attributes in the infrastructure criteria. It shows that large companies in South Korea have the capability to help establish brand value for their countries including CJ and Lotte Group, their companies have such criteria as digital infrastructure, technological expertise, especially innovative and connected to the world. So they use that capability in spreading hallyu universally. The Korean Wave way of promotion strategies of global brands also can be found in endorsement, product placement, social media and technology sharing, and distribution agreement (Kim \& Hong, 2017).

In next session, how chaebol contributes in promoting state brands in a hallyu context will be discussed in detail by measuring the various activities undertaken by chaebol using the nation branding index initiated by Simon Anholt.

\subsection{The Chaebol's Role and Its collaboration with Government through Hallyu Wave \\ 3.2.1 National Governance}

The government that sees hallyu as a profitable potential for the state immediately make the best use of it with various related regulations in order to continue to develop sustainably, even if all activities of the various agencies concerned with hallyu will be fully supported. Therefore, in the strategy carried out in order to maintain the existence of hallyu there is an official institution formed by the South Korean government that regulates all policies regarding South Korean culture, sports, and tourism related to hallyu namely MCST and various specific institutions under it (Song, 2017).

After the government, another actor who had a part in popularizing hallyu was chaebol. As explained earlier, the close relationship between chaebol and the government has been established for a long time, making it easier for the two to collaborate in the hallyu sector. There are a series of activities and various collaboration programs between the government and chaebol in order to promote hallyu globally. 
One of the largest chaebol companies focused on entertainment and culture industry is CJ E\&M. As a division of CJ Group actively engaged in entertainment, in 2018 CJ E\&M signed a business partnership with the Seoul government aimed at supporting the Seoul city brand "I Seoul U" in order to improve the image and smooth dissemination of hallyu to an international audience. According to the agreed agreement, the government will cooperatively participate in various activities held by CJ E\&M such as concerts and festivals. CJ E\&M has the main focus of spreading hallyu through mama music awards ceremony (Mnet Asian Music Awards) which has become a representative of Asia as an annual hallyu music program active for the last 20 years. Seoul city government plans to strengthen collaboration with private companies in promoting Seoul and its culture globally consistently.

In addition to the Seoul city government, CJ E\&M also contributed to the Good Hallyu program created by KOFICE. The MoU was signed by CJ E\&M on March 7, 2018 as a sign of cooperation between the government and the company with the aim of jointly developing a program to expand the scope of South Korean culture abroad. KOFICE Chairman Kim Yongrak said that marked by the MoU as a bridge of cooperation between the government and the private sector, they will strengthen international cultural exchanges and create a sustainable Hallyu ecosystem and shape South Korea's attractive image. It is also a form of government support to the activities of corporate cultural programs related to hallyu in order to expand its reach. Kim Min Gyu in charge of CJ E\&M Strategic Support also said that hallyu is no longer just a trend but has become a form of culture, and in order to create a common good they will also pay attention to the ecosystem of local communities abroad with hallyu as an intermediary media.

The cooperation is related to $\mathrm{KCON}$ and MAMA (Mnet Asian Music Award) which is a regular global cultural event by $\mathbf{C J}$ E\&M. MAMA which has been held since 1999 as an event with the concept of appreciation to musicians in the Asian region. Each year the event is held in several different countries and broadcast live through South Korea's globally accessible online platform. MAMA was one of the first South Korean cultural conventions ever attended and supported by the then President, Park Geun Hye (Kim \& Jin, 2016).

As an event that brings people together regardless of ethnicity, race, religion, and generation through music, this event plays a role in connecting South Korea with the international world that can strengthen the country's brand. CEO Mnet said that in the development of South Korean culture, the performance of The Asian market must be improved for the sake of continuing the hallyu wave in a sustainable manner. So MAMA is expected to be a program that has a big impact on the Asian market, especially South Korea in the global realm (Michel, 2014).

The next cultural festival is $\mathrm{KCON}$, the event CJ E\&M claims as an annual convention that provides the largest forum for international fans and people interested in South Korean culture to connect with each other including with players in the South Korean entertainment industry. This event has been held since the inaugural year 2012 in Irvine, United States, until now successfully held in various regions such as Europe, Australia, Southeast Asia, East Asia, to West Asia. Starting from a Kpop concert, until now KCON has become a medium that provides an experience of getting to know and integrate with South Korean culture. Visitors can also enjoy a variety of other facilities related to culture and other lifestyles such as k-fashion, kbeauty, k-food, and kdrama. Through conventions and concerts, KCON seeks to promote South Korean culture along with expanding the hallyu community to add global value to South Korean brands. 
KCON 2018 became the inaugural event since the official cooperation agreement with the government was held in 4 different cities namely Chiba-Japan, Los Angeles and New York-United States, as well as Bangkok-Thailand. Here is a list of CJ Group affiliated companies and government agencies that contributed to this event: its culinary-focused companies Bibigo and Tous les Jours, CJ Olive Young affiliated companies in cosmetics \& health, other CJ group subs such as CelebShop, CJ Logistics, and CGV Cinemas. Pemerintah Korea Selatan yang menjadi partner acara tersebut adalah Ministry of SMEs and Startups, Korea Foundation for Cooperation of Large \& Small Business (KOFCA), Korea Health Industry Development Institute (KHIDI), Korea Trade-Investment Promotion Agency (KOTRA), dan KOFICE. Disponsori oleh I Seoul U, Korean Cultural Center (KCC) dan Korea Tourism Organization (KTO).

In $2019 \mathrm{KCON}$ is back in 4 cities, with the same sponsors and partners as the previous year. Meanwhile, in 2020, due to the COVID-19 pandemic, KCON events were canceled in all cities and replaced with KCON:TACT held online. Although fans can't get in direct contact with idols, brands, and other fans, they can still enjoy a series of festive events such as 4-hour live streaming concerts, fan gatherings and interactions with 4 boy groups/girl groups every day, as well as other exclusive content.

For CJ Group affiliated companies and government agencies involved in the event, as follows: CJ E\&M, Mnet, CJ Bibigo, together with the government that supports this event such as the Ministry of Agriculture, Food, and Rural Affairs (MAFRA), Ministry of Oceans and Fisheries, Korea Agro-Fisheries \&Food Trade Corporation (aT), Korea Creative Content Agency (KOCCA) and Ministry of SMEs and Startups and KOFCA.

The next agenda was held specifically in Indonesia because the event was iLotte which has now been rebranded as iStyle, a branch of Lotte company that produces in Indonesia. In 2016, KTO Jakarta together with iStyle held a Korea Festival themed Autumn \&Winter at Lotte Shopping Avenue Jakarta in order to promote the popularity of hallyu wave to Indonesians. This event lasts for a whole month every September / October in Jakarta, covering a series of programs in the framework of Hallyu promotion in the form of K-Exhibition, $\mathrm{K}$ Performance, K-Food, and K-Content, each program has its own schedule of activities and involves a lot of parties from South Korea both government, actors and idol groups, businessmen, artists, and also chefs (Basmalah, 2016).

Government agencies that present events themed "Creative Korea - Korea Festival" such as KOCCA, Embassy of the Republic of Korea, KCC, KTO, aT, Korea International Trade Association (KITA), as well as from Indonesia, the Ministry of Tourism of the Republic of Indonesia and the Creative Economy Agency. CJ CGV, a sub-group of CJ groups engaged in the film screening network also participated in the event. Until the following years this event continues to be held annually as an effort to introduce and promote hallyu creative content from South Korea in Indonesia, as well as increase opportunities for cooperation between countries in the field of culture and creative business.

The South Korean government also directs and invites its people in the business sector to collaborate in creating systems and programs by unifying cultural content and creative economy. Production and investment were deployed in order to improve the development of South Korea's cultural content industry. Cultural Creation Convergence Center is located in CJ E\&M building within CJ Group, this base will be central in creating a series of ideas such as planning, creating, and supporting the production of such content. CJ Group will assist 78 experts in cultural content including K-Food, then expand its network with 65 cultural agencies as signed in the MOU (Kim \& Kim, 2015). At the end of 2016, KTO has also built the Cultural Creation Venture Complex as an office 
building that provides facilities for companies working in the creative and cultural industries sector, in order to integrate with each other in supporting the development of South Korean culture (Yun, 2016).

In addition, there is a Korean TV Content Showcase that has been held for the first time in 2013 and 2018 in Ukraine. The event was a forum to develop and expand South Korean broadcasting content such as $\mathrm{K}$-drama, a variety show featuring actors and K-pop idols, films, animations, and other program shows. CJ E\&M is a sub-company of CJ Group involved in this agenda(CJ, 2018). Chaebol also invested massively in the Korean film industry, and some of the chaebols that have been actively producing films are CJ, Lotte, and Orion, which control the South Korean film market by nearly 80\%. Parasite, a CJ E\&M film, became the first Korean film to win an Oscar for Best International Feature Film in 2019 strongly supported by the South Korean government. Together with KOFIC and KCC Los Angeles, they began promotions to local Media of the United States when the film was to be screened.

\subsubsection{Tourism}

Collaboration between the government and chaebol is also established in the tourism aspect. In addition to natural tourism and government-run infrastructure, South Korea also has a tourism that is owned by chaebol. One of the chaebol actively engaged in tourism is Lotte Group. In addition to producing food products, construction, and financial services, Lotte is quite superior with their various tourism facilities, including resorts, hotels, amusement parks, golf courses, malls, duty-free shopping, museums, concert halls, to provide rental services that can be used by tourists to get around in every tourist destination.

On November 24, 2020, Lotte Duty Free and CJ E\&M announced a formal cooperation agreement between the two in promoting and developing hallyu content to support tourism in South Korea. The agenda is planned to be to produce videos and content supporting k-drama, holding fan meetings with drama actors, revitalizing tourism in South Korea and preparing postpandemic tourism. These content allow domestic and international fans to enjoy a variety of content both online and offline, and is preferred to reach the people of Southeast Asia because it is expected to provide exposure to Lotte Duty Free whose branches are spread in several countries in the region, as well as increase hallyu in various sectors, especially tourism (Moodie, 2020).

Lotte Duty Free, part of Lotte Group, south Korea's first tax-free shopping mall, was built in 1980 to become the secondranked tax-free store in 2015 as the World's Leading Company in the tax-exempt industry. Since the beginning of 2010 Lotte Duty Free outlets have been widely exported in various countries, in addition online shopping sites are also accessible to the global community. Lotte Duty Free also became the first industry to do marketing with actors or idols hallyu through concerts, fan meetings, and as a model / brand ambassador in every product promotion. Lotte Duty Free not only promotes its products but has also encouraged the development of hallyu popularity with the concept of "Enter-tour-ment" a combination of tour and entertainment applied in their company. So that foreign tourists get more opportunities than just traveling and shopping, namely the satisfaction of enjoying hallyu content. Lotte Duty Free is available in many locations in South Korea, making it easy for tourists to find and shop for products without worrying about being hit by expensive taxes.

Lotte Duty Free at Lotte World Mall also provides a special location for hallyu star exhibitions labeled Star Avenue for visitors who want to experience getting closer to their idols. Visitors can view music videos, photos of idols and actors from the big screens around the studio, take pictures with them in virtual mirror zones and in studios set in various K-drama settings, as well as 
experience 3D handprints and their signatures directly. Star Avenue is also in Lotte's lotte playground, Lotte World. This place is a representative playground destination that is often visited by foreign tourists and is the largest indoor playground in the world, there are also outdoor facilities. This park is strategically built in Seoul city surrounded by other lotte tourist destinations such as Lotte World Museum, Lotte World Ice Rink, Lotte World Aquarium, Lotte Hotel, the $4^{\text {th }}$ tallest observatory tower in the world Lotte World Seoul Sky Tower, and Lotte Mall shopping center with various facilities namely Lotte Mart, Lotte Duty Free, restaurants, and cinemas (Yonhap, 2019).

In addition to Lotte Group, two CJ Group sub-companies are CJ LiveCity Corp. and CJ E\&M also has an agenda of building two cultural facilities and hallyu-themed tourist attractions that are expected to be completed in 2023, the development has the intention to increase the promotion of hallyu and South Korean tourism. The cultural facility built by CJ E\&M is located in paju city of Gyeonggi province. The project, which has been officially running since it was approved with the Paju city government in 2019, is temporarily known as CJ E\&M Content World within Paju Unification Park (Yonhap, 2019).

The cultural facilities will have 20 indoor and outdoor studios, each with a concept around hallyu content such as kdrama, kpop, kmovie. There is also a location setting for shooting historical and contemporary dramas. CJ E\&M estimates that the outdoor area can attract as many as 1.2 million visitors each year, and they also estimate that the construction of cultural facilities could open new jobs, especially in construction, hallyu content production, and management for the next decade.

In the same year and in the province, $\mathrm{CJ}$ E\&M sub-company specifically formed to manage hallyu city development project cj livecity corp. has also signed a cooperation contract in building Seoul Metropolitan Arena venues and districts with K-Culture theme. The project has been in place since 2016 but was delayed for regulatory reasons and could finally be implemented in 2019 . This destination will revitalize between South Korean culture and the national economy and Gyeonggi province. Seoul Metropolitan Arena is a major highlight in the development, for the first time South Korea will have the largest venue specifically for K-Pop music events utilizing the best technology, as most concerts are held in sports stadiums. Around the district there will also be playgrounds, hotels, and shopping centers to complement the LiveCity concept that can be enjoyed simultaneously. CJ LiveCity's location is among South Korea's largest cities, with the strategic position that visitors, especially from outside the country can reach easily, CJ livecity is estimated to attract as many as 20 million local and foreign tourists every year. The district is expected to open actively from 2024 (Roth, 2019).

Later, N Seoul Tower which since 2005 operated by CJ Group was originally built as the first radio and television transmitter tower in South Korea, is now one of the popular tourist destinations and landmarks of Seoul city which is crowded with local and international tourists. Until now N Seoul Tower has always been one of the destinations that must be included in the travel plans of foreign tourists when visiting South Korea.

Chaebol companies also open many branches of their business in Myeongdong district which is a shopping mall associated as a tourist attraction for tourists as well as representative K-culture. Among them are Lotte Department Store and Olive Young. Located in one of South Korea's most crowded tourist locations, both of the company's outlets are certainly also crowded with foreign tourists. The two often hold various interesting promos given to foreign tourists exclusively, especially in the season that is usually crowded with tourists. In addition, many of the products they provide are products that are popular with BA idols or famous actors. Olive Young's 
main outlets have provided more variety of products such as healthy food products, KPop albums, to pet needs, plus attractive zones that provide comfort such as makeup zones so that visitors can try new makeup such as their idols dressed directly by makeup artist Olive Young, game zones and cafes (Sohn, 2015).

\subsubsection{Export Promotion}

As the main export driver in South Korea, as previously described chaebol has close relations with the government both in terms of policy, permits, support, and cooperation and collaboration in various sectors including related to the hallyu cultural industry. Culture is one of the noneconomic components that have an important role in the global market. South Korea's most prominent culture is their contemporary hallyu culture, so hallyu is one of the dominant factors in underpinning South Korea's consumer goods export trade patterns in the global market (Huh \& Wu, 2017).

Lotte Corp. and CJ Group are not new players in the export world, for more than 50 years they are active in exporting for their company's diverse products. From manufacturing to lifestyle-related products such as food and beverages, health, beauty, fashion, and entertainment industries. Their contribution to the GDP of the South Korean state is also active and persistent, as in 2019 they were recorded as two companies out of a total of 64 chaebol that accounted for $84.3 \%$ of South Korea's total GDP or worth 1,617 trillion won (Song, 2020). Awareness to help the development of hallyu and promote South Korea to the international community is also implemented in every business agenda including in the field of export.

CJ started its first export in the first 5 years since the company was founded, the product exported at that time was sugar. Until now CJ group is actively expanding in several regions, namely East Asia, Southeast Asia, the United States, and Europe. One of the largest exporters of CJ Group's ownership company operating in the food industry is CJ CheilJedang Corp, among its products there is a brand called Bibigo that represents the taste of South Korean food and has a combination of traditional and modern cultural values of the country. One of Bibigo's intentions distributed globally is for the world community to understand food that contains the philosophy and life of South Korean people authentically.

Bibigo became the first South Korean product with total sales of 1 trillion won, and one of the brand's product variants is Bibigo dumplings or mandu in Korean, during the last 5 years the sales rate of its exports continues to increase to 670 billion won by 2020 , even that figure exceeds the domestic sales level. Its main markets are in the United States, China, Japan, Vietnam, and countries in the European region (Kim, 2021a). CJ hopes that Mandu Bibigo will be able to bring the global community to try other South Korean foods to get them to know South Korean culture in its entirety.

Another food product, a traditional South Korean sauce known as gochujang, received enthusiasm as evidenced by the differences in the export value recorded from 2016 of 31.3 million USD and in 2020 amounted to 301.7 million USD, the largest export destination in the United States ( $\mathrm{Jo}_{\text {, }}$ 2021). One of the largest exporters for gochujang is CheilJedang Corp. of Bibigo and Haechandle brands, at KCON USA in 2018 they provide their own booth for visitors who want to experience gochujang directly in order to promote the taste of South Korea. In order to participate in the market of diversification and attract Muslims in the world, CheilJedang Corp. created gochujang non-alcoholic and other non-halal ingredients that are further exported to countries with the largest Muslim population in the world, namely in the Southeast Asia and Middle East. For gochujang from CheilJedang itself recorded since the first export in 2013 the quantity of exported products increased from 5.1 tons to 7.2 in 2017 (Choi, 2018). 
In addition to food, CJ Group has an affiliated company focused on beauty. Nowadays, the use of cosmetics and skincare is no longer a trend but has become a necessity and lifestyle. South Korean beauty products themselves are favored for their good quality and continue to produce innovations. CJ Group's affiliated company that operates in the field of beauty and health products that sells from various local South Korean brands is CJ Olive Young. Olive Young has many outlets in South Korea and the most popular especially for foreign tourists are the outlets located in Myeongdong and Gangnam. Olive Young's offline outlets also since a few years ago began to be exported in other countries starting from Shanghai and Hongkong. Olive Young stated that it will continue to strive to expand its outlets in other countries, especially in Southeast Asia in order to increase the spread of K-beauty products in the global realm (Son, 2021).

The export of K-beauty products looks to be growing rapidly, especially through online platforms. In addition to the growing popularity of hallyu, the government's decision to reduce restrictions on duty-free purchases has led to an increase in exports. Olive Young has the intention to expand the popularity of K-beauty globally by supporting all brand classes from small to large local companies. Olive Young also has an online store that makes it easy for customers from overseas to shop practically, in the last year. One year since it first opened, there has been a 50 percent increase in online sales growth. Olive Young stated that the creation of Olive Young global shopping mall is a hub that can introduce and promote local South Korean products to international customers in order to globalize K-beauty products. CJ Olive Young has collaborated with e-commerce companies in other countries such as Rakuten Japan, Tmall and Kaola in China, and the network will be expanded again in other countries as well (Kang, 2020).

In Japan Olive Young started to open online outlets because of the high enthusiasm of the Japanese people towards K-beauty. It is based on the consideration that there is data in 2017 that shows $46 \%$ of the total population in Japan like to shop online (Choi, 2021). Since 2 years ago Olive Young has agreed with the largest distributor company in Southeast Asia to open offline and online business opportunities, it is realized in 2021. Due to Covid-19, the expansion is more focused through digital platforms through cooperation with one of the largest e-commerce in Southeast Asia, Shopee, and started from Indonesia and Malaysia. Olive Young's business expansion strategy has a different approach, for countries in Southeast Asia and China, CJ collaborates with distributor companies in the region. Olive Young Global's website is intended for shipments that can be accessed directly in the United States and Europe.

As one of the chaebol initiators of hallyu content, CJ E\&M, which is very active in the entertainment industry, has been exporting a wide range of products such as film, music, drama, and other culturally based content since the mid-1990s and is growing to this day. Sales and screenings of films reached more than 500 films with a total of 750 million viewers as of 2020. For K-drama, partnerships with global streaming media companies are conducted with Netflix and Studio Dragon and export global sales in more than 200 countries. While their reality and variety shows have been exported to about 160 countries, some of its shows have been rated on one of the largest television channels in the United States, wild Korea documentaries even being the major winners at the New York Festivals TV \&Film Awards. Superstar K and I can See Your Voice music events were exported in more than 9 countries, which gained the enthusiasm of the local community so that it was reproduced in those countries, then the last there was an animated production of $\mathbf{C J}$ E\&M that has been exported to 91 countries in the world. Through CJ E\&M's Stone Entertainment agency, they also produce and distribute K-Pop music overseas. In addition, through various conventions and 
festivals that they hold every year such as KCON and MAMA encourage their products to be easier for people to touch directly.

CJ E\&M's division in the cinema business is CJ CGV which has exported many of their cinema multiplex businesses in several regions of the world such as the United States, East Asia, Southeast Asia, Australia, the Middle East, and Europe. Since it first opened in 1998, CJ CGV until 2018 has recently grown significantly to become one of the 5 largest cinema companies in the world with 3,456 screens spread across 463 cinemas in the world. It said that CJ CGV will focus on the expansion of the cinema market from South Korea and the idea of a cultureplex (culture multiplex) globally aimed not only at movies but all other forms of entertainment content (Lee, 2018b).

In 2016 CJ CGV held a stand and held a meeting with cinema company owners from around the world at CinemaCon Los Angeles. This event was held in order to disseminate cinema hallyu to the global market. CJ E\&M introduces the results of the latest technology project in the world of 4DX. The activity is claimed to be an opening of a wider avenue in the export activities of South Korean cinema and film businesses to the international market (Marie, 2016).

From CinemaCon, partnerships were made with many companies from other countries, including in 2017 CJ CGV released 23 4DX bioxop in Australia and became the final line of export target plans to 50 countries in the world. CJ CGV became a cinema multiplex company that developed very quickly both domestically and globally. In 2020, CJ CGV signed a partnership with Watcha, a streaming platform company, to make the expansion and distribution of the film business easier and wider (Kim, 2020).

In addition to CJ Group, Lotte Group is also a long-time player when it comes to export activities. Starting with the export of chewing gum, until now Lotte has exported many variants of its products to various countries around the world. An affiliate company that produces in the snack food sector and is lotte group's first company is Lotte Confectionary, Lotte Conf. became the first snack food company to produce 5 trillion won in its export activities. So the results of Lotte Confectionary's own export activities have an important impact on the South Korean economy and they stated that they will continue to strive to play their part in developing south Korea's food industry globally. Until now its products have been exported to dozens of countries in the world with the construction of overseas production bases in 8 countries.

One of its famous products is Pepero, a biscuit stick coated in cream dough with various flavors. Pepero's existence in South Korea is no longer just an ordinary snack but has entered into the culture of Koreans who are known to enjoy celebrating. Pepero became a symbol on every November 11 as a day of affection to the closest people or coworkers by giving them Pepero, the day known as Pepero Day. Pepero, which uses idol group EXO as a brand ambassador since 2014, is listed as one of the most exported products by Lotte Confectionary, total sales of Pepero accumulated reached 1.6 trillion won. Because of using EXO as BA, even often hold events with the bonus of getting a photocard of the group members if giving some bundles of Pepero products, so Pepero is very famous in the global community, especially among fans (Park, 2017).

Lotte Entertainment, which has now been rebranded as Lotte Cultureworks is an affiliate company of Lotte Group operating in the film sector, with production, investment, distribution, international export, and exhibition activities. Lotte Cinema which is an affiliate company under Lotte Cultureworks to date has exported to 40 countries in the world. efforts to continue expanding its network in Southeast Asia until 2022. To date their cinema business has exported as many as 179 locations in Vietnam and 96 locations in China. In Vietnam, Lotte Cinema focuses on 
continuing to expand its network in the 5 largest cities and participates with local production houses by investing and producing films together. While in Indonesia has exported as many as 5 cinemas and is looking for partners with the largest shopping centers in Indonesia to expand its cinema business and participate in production activities. Lotte Cinema thinks that entering new markets will have a good impact in opening up the diversification of their hallyu content programs, so that expansion to other countries will continue to be pursued (Lee, 2018a).

For K-beauty and K-fashion content, Lotte Group has a special affiliate company that is an exporter of these products, namely Lotte Duty Free and Lotte Shopping Avenue. Since 2012 Lotte Duty Free has exported its outlets in various cities outside South Korea including Indonesia, Guam, New Zealand, Australia, Vietnam, Singapore, and Japan, so that the global community can more easily access authentic beauty and fashion products from South Korea at their nearest outlets. To date they have opened 20 outlets in 7 countries, and will continue to strive to present hallyu and expand into a shopping mall that provides global South Korean products. Lotte Duty Free also has an online shopping site that can be used by customers who are traveling and goods can be picked up when they arrive at the airport that has Lotte Duty Free outlets inside.

One of the countries that often collaborates with Lotte Group is Indonesia. In addition to expanding its outlets, production centers and exporting products, Lotte Group opened an online shopping site specifically in Indonesia called iStyle. Previously named iLotte but because they decided that will narrow the focus of sales type lifestyle, so rebranded into iStyle. On the site there is a wide range of products such as fashion, beauty, sports, and daily needs. These products are exported directly from South Korea, and there are also products from local brands in Indonesia. iStyle also often holds hallyu events and festivals that are held annually for fans in Indonesia. Lotte Shopping Avenue, which also opened a branch in Indonesia, has a similar online shopping site. Exported products also come from South Korea and brands from other countries such as Indonesia, United States, and China.

The explanation is an example that shows how the participation and activities of CJ and Lotte Group in developing hallyu content that further affects the value that the global community gives to the South Korean state. From export activities, the products distributed by both companies will be easier to reach by the international community so that the public will also be easier in measuring the quality of those products.

\subsubsection{Investment \& Immigration}

CJ Group began its direct hallyu expansion in Southeast Asia by its affiliated company in the entertainment sector $\mathbf{C J}$ E\&M, starting in Vietnam in 2016 by investing in hallyu content production infrastructure in the broadcasting sector and acquiring blue group company worth 10 billion won, one of the largest production companies and content agencies in Vietnam which subsequently re-branding under the $\mathrm{cj}$ blue corp name. This was implemented as CJ E\&M's strategy to create hallyu content in the field of entertainment and broadcasting tailored to the intended country to make it more acceptable to its people. As in Vietnam, through the True CJ Creations program, CJ E\&M will also localize hallyu content in Thailand. Programs such as Kdramas, talent shows and competitions will be reproduced involving Thai people. One of them is Let Me In, a program that tells the process and results of one's makeover, became a popular program in Thailand and received a rating of $4.5 \%$. $\mathrm{CJ}$ is determined to be the most superior Asian company in spreading hallyu content in business and culture (Jung, 2016).

Since its success with Parasite, CJ E\&M has been increasingly eager to continue producing and disseminating hallyu content in the field of broadcasting. CJ E\&M said it 
was investing more than 5 trillion won over the next 5 years. Strategies include being consistent in producing massive variety shows, movies, and animation programs, as well as channeling more movies and $\mathrm{K}$ drama through Netflix, a global streaming platform that is currently very popular. CJ $\mathrm{E} \& \mathrm{M}$ who has experience in producing talent show programs to become idols such as Produce 101, Produce 48, i-Land, Idol School, and other programs will prioritize his business in similar K-pop content as well. The content will be produced outside Of South Korea to explore the talents and interests of the international community in the K-pop industry, so business cooperation with local content creator companies will also be expanded in in the intended countries such as Asia, the United States, and Europe (Kim, 2021b).

In particular CJ E\&M invested 25.3 billion won only for the Kpop industry, with additional donations from investment firm KC Ventures worth 300 million won. The investment fund will be used to support South Korea's music industry, ensure sustainable development of Kpop content, and help artists and content creators financially. This fund will be operated by CJ E\&M for the next 7 years, and they plan if the investment fund can grow even bigger in the future (Yonhap, 2020).

Speaking of the program of events that will be opened in countries outside South Korea, it also relates to the immigration aspect in the nation branding. Almost all of the talent show's programs are made open to citizens from anywhere, not limited to South Koreans. Generally, teenagers and young adults from around Asia, such as Taiwan, China, Japan, Thailand, and Indonesia were found to participate in the competition. The concept of the talent search program is to find people who if they have the ability to perform as idols, after going through a series of auditions, some of the selected participants will be contracted by the organizing company to settle in South Korea and be debuted as an idol group. Chaebol who actively held a talent search event to be debuted as an idol group is CJ E\&M, there are about 10 shows commonly called idol survival shows with differentiation concepts in each program of the show but with a similar system. This led more and more people to try their luck by auditioning or competing, requiring them to settle in South Korea. One example is Canadian idol Mark Lee who made his NCT debut in 2016 through SM Entertainment's global auditions, encouraging his family to follow Mark and settle in South Korea.

After successfully hosting a show that has successfully debuted many idol groups, CJ E\&M in collaboration with HBO Max began production of the latest talent show program for the Latin American market. The winner of the audition will be flown to South Korea to be trained directly according to the Kpop training system and then debuted into an idol group under CJ E\&M. The selection of South America as one of CJ E\&M's destination countries to start the inaugural program that will be recorded as the initiator in hallyu history is due to the growth of the country's entertainment industry is quite potential, according to data from IFPI Music Global the growth of the South American music industry averages $18.9 \%$ annually which is even higher than the global average figure. In addition, Spanish, which is mostly spoken by South American people and is the second most widely spoken language in the world, will help facilitate the spread of hallyu globally. This collaboration of K-pop content and local Characteristics of South America can prove CJ E\&M's ability in the field of hallyu content production in the global market (Dong, 2021).

In the K-food sector, CJ Cheiljedang has also invested 70 million won and has been working to expand its food business in Vietnam since 2017. This production center mainly produces variants of Bibigo foods such as dumplings and kimchi as well as other frozen foods. CJ Cheiljedang blends $\mathrm{K}$-food culture with local food culture in Southeast Asian markets, and will continue to invest in all facilities and agendas that 
impact the company's growth and development of K-Food (Choi, 2017).

Since 2016, CJ Group has set a vision for South Korea's development stated directly by CJ Group President Lee Jae Hyun, that they have a framework established in the business of the cultural sector in which there is a setting of goals and objectives, preparation of programs and implementation strategies. Among their goals is to become one of the best global companies and improve the quality of national brands through hallyu industrialization. CJ Group CEO Lee Chae Wook said their company will make every effort to grow sales in the industry and collaborate with the largest cultural companies on a global scale (Yonhap, 2017).

Similar to CJ Group, Lotte Group is also the CEO of Lotte Duty Free said directly that Lotte Duty Free has invested a considerable amount of budget as well as organizing events containing hallyu content, the move is intended to attract foreign tourists to come visit South Korea so as to have an impact in improving the competitiveness of South Korean tourism (Rozario, 2016).

Lotte Group formed Lotte Cultureworks, a rebranding affiliate of Lotte Entertainment that specializes in South Korean film. The company focuses on investing in, distributing, and screening film exhibitions. In its investment program, Lotte Cultureworks has invested heavily in various films that are subsequently distributed for international sales. Then, one of the main programs was to inject 10 billion won into a project called Busan-Lotte Creative Film Fund. The agenda was part of the Creative Economy Action Plan formed by President Park Geun Hye at the time. The funds will then be used to support South Korean cinema from pre to post-film production, sales, and film distribution. Busan was chosen because the Busan International Film Festival is an Asian film festival (Park, 2016). Lotte Cultureworks division which manages the multiplex cinema business, Lotte Cinema also continues to strive to invest, distribute, and export many films every year, in order to promote and expand the cinema business and export South Korean films abroad.

From a series of activities both in terms of investment to persuasion the interest of the foreign community to have affiliation with the Korean state Sealatan both work to settle shows the efforts made by chaebol in order to expand the reach of hallyu globally which then greatly impacts in giving a good impression of the international community that can affect the addition of brand value for South Korea.

Based on the explanation that has been described above on how the role of chaebol to south Korean branding through hallyu wave by using the nation branding index element as a benchmark of the extent and what contributions chaebol makes, it can be withdrawn the result that not all elements can be used to explain chaebol collaboration as a business sector and government in encouraging the addition of the value of South Korean state image. The elements that managed to become indicators were able to prove the role of chaebol, especially $\mathrm{CJ}$ and Lotte Group with their collaboration with the government but in different proportions. Researchers chose to analyze CJ and Lotte Group companies because they are both chaebol companies that are most active in promoting hallyu through almost every business activity. As a company that carries the value of culture and lifestyle it makes it easier for them to bring hallyu to reach the community and close to their daily life.

Regarding some of the elements that show the most contribution from CJ and Lotte Group in its collaboration with the government both in the form of direct support such as sponsorship, cooperation, joint venture to matters related to policies and licensing, which can provide or add new value to the South Korean state, among others are elements of national governance, export, tourism, as well as investment \& immigration, which further leads to the addition of value in the nation's image and place branding given by the international community and then impact on the national 
economy of South Korea. As explained earlier that branding targets not only concentrate on the formation of names, symbols, and figures but also focus on developing and marketing products directly in the international realm.

\section{Conclusion}

Hallyu apparently brought a lot of influence and positive impact to the country. Seeing the potential of cultural exports that have a very good effect on the expansion of South Korea's economic branding, finally served as one of the nation branding strategies by the government carried out through chaebol, also fully supported by the government with a variety of policies that facilitate them in developing. It has the meaning that the government's efforts in the welfare of the country and its people turned out to be able to package it as a tool or means to do nation branding, in order to have its own bargaining in the international world, because in the current era all are required to be creative, so that South Korea also innovates and hones its creativity by producing products from the export of culture with attractive packaging.

Based on the explanation that has been described above on how the contribution of chaebol to South Korean branding through hallyu wave by using the nation branding index element as a benchmark of the extent and what contributions chaebol makes, it can be withdrawn the result that not all elements can be used to explain chaebol collaboration as a business sector and government in encouraging the addition of the value of South Korean state image. The elements that managed to become indicators were able to prove the contribution of chaebol. Each of their subsidiary company of chaebol has its specialized activities such as CJ E\&M that engages in business activities in the entertainment sector (K-pop, K-drama, Kfilm) if measured by the cultural elements of their role as evidenced by the various music conventions and festivals or drama production. As a company that carries the value of culture and lifestyle it makes it easier for them to bring hallyu to reach the community and close to their daily life according to the business sector they run.

In general, authors hope that other country can learn how South Korea really cares about their national brand. The establishment of a special institution, the formulation and implementation of policies, and the unification of various parties to support the development of the South Korean state in terms of image which in turn will have an impact on national economic growth. It would be very interesting to look out how such nation like Indonesia could also maximize efforts to strengthen national brands which would certainly give a good snowball effect to other aspects.

\section{References}

Akarsu, M. Z. (2021). Chaebol system. International Journal of AfroEurasian Research, 6(12), 1-13. https://dergipark.org.tr/en/download/a rticle-file/1537038

Anholt, S. (2013). Beyond the nation brand: The role of image and identity in international relations. Exchange: The Journal of Public Diplomacy, 2(1). https://surface.syr.edu/exchange/vol2/ iss $1 / 1$

Aziz, N. L. L. (2016, November 30). Hubungan kerjasama pemerintah dengan pihak swasta dalam pembangunan infrastruktur di Indonesia [Artikel]. Pusat Penelitian Politik

LIPI. http://www.politik.lipi.go.id/kolom/k olom-1/politik-lokal/1107-hubungankerjasama-pemerintah-dengan-pihakswasta-dalam-pembangunaninfrastruktur-di-indonesia

Basmalah, N. (2016). Siap-siap, K-Pop dan Korea festival segera digelar di Jakarta. Liputan6. https://www.liputan6.com/global/read /2606224/siap-siap-k-pop-dan-koreafestival-segera-digelar-di-jakarta 
Campbell, T. L., \& Keys, P. Y. (2002). Corporate governance in South Korea: The chaebol experience. Journal of Corporate Finance, 8(4), 373-391. https://doi.org/10.1016/S09291199(01)00049-9

Chae Yun-Hwan. (2019, May 15). FTC names 59 chaebol to 2019 watch list. Korea Joong Ang Daily. https://koreajoongangdaily.joins.com/ 2019/05/15/economy/FTC-names-59chaebol-to-2019-watchlist/3063132.html

Choi, D., \& Kim, P. S. (2014). Promoting a policy initiative for nation branding: The case of South Korea. Journal of Comparative Asian Development, 13(2), 346-368. https://doi.org/10.1080/10548408.201 4.926804

Choi, J. (2021, June 1). CJ's cosmetics retail wing starts Japanese service through online shopping mall. AjuDaily. https://www.ajudaily.com/view/2021 0601134516225

Choi, M. (2017, July 26). CJ Cheiljedang to ramp up investment in food business in Vietnam. Business Korea. http://www.businesskorea.co.kr/news/ articleView.html?idxno $=18777$

Choi, S. (2018, September 9). CJ Cheiljedang eyes expanding exports of traditional Korean sauces. Yonhap News Agency. https://en.yna.co.kr/view/AEN201809 09000300320

CJ Companies to Build "Hallyu-Themed" Cultural facilities near Seoul. (2019, June 19). Yonhap News Agency. https://en.yna.co.kr/view/AEN201906 19002800315

CJE\&M leads "Nice Hallyu" with KOFICE. (2018, March 13). CJ CSR activities. https://english.cj.net/cj_now/view.asp ?bs_seq $=13865 \& \operatorname{schBsTp}=3 \&$ schTxt $=\mathrm{K}-\mathrm{CULTURE}$

CJ ENM's 25.3 Billion won K-Pop Investment fund to launch. (2020, January 20). Yonhap News Agency. https://en.yna.co.kr/view/AEN202001 20004100315

CJ poised to speed up investment as head returns from pardon. (2017, February 26). Yonhap News Agency. https://en.yna.co.kr/view/AEN201702 26000700315

Dillinger, J. (2019, June 5). The world's 20 largest exporting countries. WorldAtlas. The World's 20 Largest Exporting Countries

Dong, S. (2021, June 5). CJ ENM to launch new k-pop-inspired boy group in Latin America. The Korea Times. https://www.koreatimes.co.kr/www/a rt/2021/05/732_308411.html

Huh, C.-G., \& Wu, J. (2017). Do Hallyu (Korean Wave) exports promote Korea's consumer goods exports? Emerging Markets Finance and Trade, 53(6), 1388-1404. https://doi.org/10.1080/1540496X.20 17.1313161

Jo, H. (2021, February 12). How Korean food is rising to capture the world's palate. http://www.koreaherald.com/view.ph p?ud=20210210001004

Jung, D.-H. (2004). Korean Chaebol in transition. China Report, 40(3), 299303.

https://doi.org/10.1177/00094455040 4000306

Jung, M. (2016, October 17). CJ E\&M Targets southeastern broadcasting content market. Business Korea. http://www.businesskorea.co.kr/news/ articleView.html?idxno=16213 
Kang, J. (2020, June 11). Olive young's online store proves popular overseas. Korea Joong Ang Daily. https://koreajoongangdaily.joins.com/ 2020/06/11/business/industry/oliveyoung-CJ-Olive-YoungCJ/20200611192800238.html

Kim, B. (2015). Past, present and future of hallyu (Korean Wave). American International Journal of Contemporary Research, 5(5), 154160.

https://www.aijcrnet.com/journals/Vo 1_5_No_5_October_2015/19.pdf

Kim, B. (2021a). CJ ENM to invest 5 trillion won in content over next five years. Yonhap News Agency.

Kim, B. (2021b, May 31). CJ ENM to invest 5 trillion won in content over next five years. Yonhap News Agency. https://en.yna.co.kr/view/AEN202105 31005200315

Kim, N.,\& Hong, L. (2017). The power of culture in branding: How the Korean Wave can help global brands thrive in Asia. Journal of Brand Strategy, 6(3), 293-307.

Kim, S. (2020, November 20). Korea set to crack down on Chaebols with corporate reform. Bloomberg. https://www.bloomberg.com/news/art icles/2020-11-19/korea-set-to-crackdown-on-chaebols-with-corporatereform-steps

Kim, S. M., \& Park, M. J. (2020). Evaluation of cross-national global market segmentation and strategy: The case of Korean Wave for ASEAN countries. Asia Pacific Management Review, 25(4), 207-215. https://doi.org/10.1016/j.apmrv.2020. 04.001

Kim, S., \& Kim, S. (2015, December 2). Gov't to invest $\$ 900 \mathrm{mn}$ in Hallyu valley.

PulseNews. https://pulsenews.co.kr/view.php?yea $\mathrm{r}=2015 \& \mathrm{no}=143748$

Kim, T. Y., \& Jin, D. Y. (2016). Cultural policy in the Korean Wave: An analysis of cultural diplomacy embedded in presidential speeches. International Journal of Communication, 10. https://ijoc.org/index.php/ijoc/article/ view/5128/1838

Kim, Y. (2020, November 10). CJ CGV and OTT platform watcha sign agreement on mutual cooperation. https://koreajoongangdaily.joins.com/ 2020/11/10/entertainment/movies/CG V-Watcha-CJ-

CGV/20201110172600502.html

Lee, H. (2018a, July 10). South Korean exhibition giant cj cgv to triple global screen count by 2020. The Hollywood Reporter.

https://www.hollywoodreporter.com/ business/business-news/south-koreanexhibition-giant-cj-cgv-triple-globalscreen-count-by-2020-1125885/

Lee, H. (2018b, November 3). Head of South Korea's Lotte Group on new entertainment division cultureworks. The Hollywood Reporter. https://www.hollywoodreporter.com/ news/general-news/head-lotte-groupcultureworks-collaboratinghollywood-1157786/

Lee, S. (2020). Hallyu in broadcast programs A new wave of change, for a leap forward. In '19 Hallyu White Paper (1st ed., pp. 10-33). Korean Foundation for International Cultural Exchange.

https://home.kocca.kr/mportal/bbs/vie w/B0000204/1943622.do;KCSESSIO NID=96MLgS6KkdfVW1xBrf68shry fRwf7rjjmJ4yhGV8qrppJMqtFZQS!337396942 ! 791589242 ? search $\mathrm{Cnd}=\&$ searchWrd $=\&$ cateTp $1=\&$ cateTp $2=\& u$ 
seAt $=\&$ menuNo $=201360 \&$ categorys $=4 \&$ subcate $=59 \&$ cateCode $=0 \&$ type $=$ \&instNo $=0 \&$ question $\mathrm{Tp}=\& u f \_S e t t i n g$ $=\&$ recovery $=\&$ option $1=\&$ option $2=\&$ year $=\&$ categoryCOM062 $=\&$ category COM063 $=\&$ categoryCOM208 $=\&$ cate goryInst $=\&$ morePage $=\&$ delCode $=0 \&$ $\mathrm{qtp}=\&$ searchGenre $=\&$ pageIndex $=2 \#$

Levy, J. S. (2007). Qualitative methods and cross-method dialogue in political science. Comparative Political Studies, 40(2), 196-214. https://doi.org/10.1177/00104140062 96348

Marie. (2016, April 19). CJ CGV Spreads 'Cinema Hallyu' at 2016 CinemaCon. Business Korea. http://www.businesskorea.co.kr/news/ articleView.html?idxno=14447

Marquet, J. R. (2013). The unique story of the South Korean film industry. INA Global.

Michel, P. (2017, December 4). This threecountry, four-night AsianMusic Awards Show is a k-pop promotion machine. $N P R$. https://www.npr.org/sections/therecor d/2017/12/04/568292038/this-threecountry-four-night-asian-musicawards-show-is-a-k-pop-promotionmachi

Moodie, M. (2020, November 25). Lotte Duty Free strikes Korean Wave MOU with entertainment company CJ ENM to drive tourism and spending revival. The MoodieDavit Report. https://www.moodiedavittreport.com/ lotte-duty-free-strikes-korean-wavemou-with-entertainment-company-cjenm-to-drive-tourism-and-spendingrevival/

Nguyen, A., \& Özçaglar-Toulouse, N. (2021). Nation branding as a marketshaping strategy: A study on South Korean products in Vietnam. Journal of Business Research, 122, 131-144. https://doi.org/10.1016/j.jbusres.2020. 08.029

Park, G. (2017, January 20). Exports boost Korean confectionary growth. The Korea Herald. http://www.koreaherald.com/view.ph $\mathrm{p} ? \mathrm{ud}=20170120000526$

Park, H. (2016, March 2). Busan, Lotte launch fund for sustainable movie ecosystem. The Korea Herald. http://www.koreaherald.com/view.ph p?ud=20160302000795

Rahayu, S., \& Arianti, R. K. (2014). Persepsi national branding sebagai upaya meningkatkan kinerja ekspor ke Jepang dan Australia. Buletin Ilmiah Litbang Perdagangan, 8(2), 183-208. https://doi.org/10.30908/bilp.v8i2.82

Roth, M. (2019, June 10). CJ LiveCity Corporation and AEG to jointly pursue building Korea's first world class arena. Bloomberg. https://www.bloomberg.com/pressreleases/2019-06-09/cj-livecitycorporation-and-aeg-to-jointlypursue-building-korea-s-first-worldclass-arena

Rozario, K. (2016, April 25). How hallyu still powers South Korean duty free. $T R$ Business.

https://www.trbusiness.com/regionalnews/asia-pacific/how-hallyu-stilldrives-korean-duty-free/104480

Sohn, J.-A. (2015, August 19). Tourists to benefit from nation-wide sale. Korea.Net.

https://www.korea.net/NewsFocus/So ciety/view?articleId=129406

Son, M.-J. (2021, June 14). CJ Olive Young will be in mannings, introduce $\mathrm{K}$ Beauty in greater China. Global Economic News. https://men.g- 
enews.com/view.php?ud=202106141 756173591c4c1a19e2e_9

Song, C. K. (2020, June 14). S. Korean chaebols comprise $84 \%$ of GDP but only $10 \%$ of jobs. Hankyoreh. https://english.hani.co.kr/arti/english_ edition/e_business/949236.html

Song, S. H (2020, July 17). South Korean government's hallyu department announces plans to support hallyu expansion. The Jakarta Post. https://www.thejakartapost.com/life/2 020/07/17/south-koreangovernments-hallyu-departmentannounces-plans-to-support-hallyuexpansion.html

Walsh, J. (2014). Hallyu as a government construct: The Korean Wave in the context of economic and social development. In Y. Kuwahara (Ed.), The Korean Wave (pp. 13-31). Palgrave Macmillan US. https://doi.org/10.1057/97811373502 82_2
Yoo, I. (2008). Korea's economic development: Lessons and suggestions for developing countries. Korea Social Science Journal, XXXV(1), 31-63. http://www.kossrec.org/wpcontent/uploads/2015/04/KSSJ_2008 06_2_유일호.pdf

Yun, S. (2016, August 8). Cultural venture complex aims to attract investment. The Korea Times. https://www.koreatimes.co.kr/www/c ulture/2021/08/135_211423.html 